Orissa Journal of Commerce

Vol. 42, Issue 1, Jan-March 2021

ISSN: 0974-8482

(C) OJC India. All Right Reserved

URL : www.ojcoca.org

DOI: https://doi.org/10.54063/ojc.2021.v42i01.09

\title{
Financing Higher Education through Education Loan in India: Current Status, Challenges and Future Prospects
}

\author{
Krishnan Chalil \\ Professor \& Head, Department of Development Studies; \& Dean, School of Social Sciences and Policy, \\ Central University of South Bihar, Gaya,Bihar.E-mail:drckecalicut@gmail.com
}

To cite this paper

Chalil, K. (2021). Financing

Higher Education through

Education Loan in India: Current

Status, Challenges and Future

Prospects. Orissa Journal of

Commerce. 42(1), 116-131.

Keywords

Commercial banks, Education

loan, Model education loan

scheme, GER, Regional disparity

JEL Classification

I22, I23, I28

\begin{abstract}
The increasing demand for higher education and the fiscal constraints faced by the government has resulted in the evolution of 'Education Loan' as an alternative source of funding higher education in India. Since the announcement of the Model Education Loan Scheme in 2001, the commercial banks have come forward to finance higher education on a wider scale. Though there has been a spectacular increase in education loan over a period of time, the scheme has met with several challenges. In this background, we make an attempt to examine the growth of higher education in the country, the growth of education loan and its regional distribution. The study found that there has been continuous increase in higher education enrolment through diversified institutions. Consequently, the education loan has also witnessed remarkable rise during the study period. However, a look at the dispersal of education loan shows its skewed distribution among various states and regions. The study concludes that the uneven distribution of education loan vitiates the very purpose of this scheme.
\end{abstract}

\section{Introduction}

The demographic dividend and the corresponding demand for tertiary education has put much pressure on our existing higher education sector. It is a fact that the increasing demand for higher education cannot be met through government funded institutions alone. This has resulted in the mushrooming growth of many private institutions to cater to the rising aspirants of higher education. The policy of globalization and its dimensions like the opening of the economy and increasing role of the private sector have opened more opportunities for the educated workforce. The writings of Schultz (1961), Stiglitz $(1998,2003)$ and Romer (1990) have convincingly reiterated the role of education and knowledge in promoting growth of an economy. The human capital theories and the thrust on human development compelled the Third World Countries also to initiate mechanisms to expand education opportunities. However, the fiscal constraints and the consequent developments have slowly compelled the government to opt for some alternative ways of addressing the increasing demand for higher education. These policies have brought the 'market' to the centre stage of the provision of education. Now, both the market and the government are complementary service providers in higher education. 
While subsidized education is available in the public sector higher education sphere, the cost of education is far higher in the private sector. So, the poor, but, meritorious students may not find access to higher education in the private sector. So, the government of India thought of bringing the banking sector to the forefront through the development of a new portfolio known as the 'Education Loan Scheme'. It is also to be kept in mind that education loan in many forms are in vogue in many countries of the world. Accordingly, The Model Education Loan Act was announced in 2001 by the Indian Banks Association (IBA) and all the commercial banks were advised to sanction education loan as per the provisions contained in the Act. Since then the commercial banks have been providing education loan to the students pursuing professional and non-professional higher education programmes. Now, almost two decades are over after the promulgation of the Model Education Loan Act and as such a look at the working of this scheme is imminent. A few scholars like Varghese (2009) and Rani (2014) have already pointed out that the education loan scheme has failed to address the question of equity in education. To make the education loan effective, efficient and equitable, a revisit of the progress of the scheme is needed and this study is conducted in such a background.

\section{Review of Literature}

Ganguly and Raj (2020) made an attempt to analyse the determinants of default in education loans in Tamil Nadu. The study was based on the account level data of over two lakh education loan beneficiaries of two public sector and one private sector banks. The main purpose of the study was to identify the major predictors of default. The results of the study suggest that loan accounts with higher interest rate and of lower duration have higher default probability while loans extended to accounts with Aadhaar information, collateral backing or some subsidy element have lower risk of default.

Krishnan (2020) in a recent research report found that education loan is beset with several inadequacies. The skewed distribution of education loan, high overdue and the laxity of the private commercial banks in the provision of education loan were the crucial issues threatening the continuous flow of education loan in India. Tiwari and Ravi Kumar (2019) in their study covering sample from both the private and public sector commercial banks found that rising cost of education compels the families to seek refuge in education loan.

Rani (2016) in her paper found that student loan has become one of the novel methods of financing education in India. The commercial banks education loan portfolio seems to be an attempt to ease out the imperfections prevailed in the capital market. So, the government of India have promoted education loan on a large scale. However, the author found it very difficult to define the terms like meritorious but poor student clause, affordability etc., as contained in the Model Education Loan Act 2001. In another context Rani (2017) examined the question whether the government expenditure on higher education and education loan is substitutes or complements.

In the light of the shifting of the burden of financing higher education from the government to the household, Duraisamy and Duraisamy (2016) discuss the pattern of public outlay on higher education and the methodologies adopted by the government to meet this increasing expenditure. The study specifically looks at the efficacy of education loan as a mechanism to ease the burden of the government and the household. The study makes use of the National Sample Survey unit level data set. 
Panigrahi (2010) brought to the fore several issues confronting education loan scheme such as gender, region and discipline barriers. The banks generally differentiate the beneficiaries on the basis of gender, regions etc. Generally, the rural and female students are not getting equal treatment as given to the urban and male beneficiaries. The procedural and attitudinal issues of the bank were also discussed in her study. Narayana (2005) examined the level of education loan offered by the commercial banks with respect to the estimated budgetary subsidy allocation of Karnataka based colleges. Even if the student loan compensates for the budget allocation subsidy for higher education, student fee hike is not a suggestable model for countries like India.

Chattopadhyay (2007) argues that due to the imperfections of capital market and also various types of discriminations practiced by the banks, it is not advisable to promote education loan as a potential source of higher education finance in countries like India. In addition, the imperfections in the job market also make it more complex. Puttaswamaiah (2010) has analysed the performance of public sector banks in the provision of education loan with special reference to Canara Bank and State Bank of Mysore. Though the education loan is included in the priority sector credit portfolio, the bank lending to education comes only 3.7 per cent of the total priority sector lending in the year 2009. Barr (1993), addresses the issues related to the funding of higher education in United Kingdom. Among other methods of financing higher education, education loan has been prevalent in the UK for quite some time, However, it has failed to address the equity and efficiency issues. So, he argues for a coherent strategy for higher education funding.

It is clear from the aforesaid studies that there are only limited studies in the area of education loan by commercial banks. Those studies which addressed the issue of education loan form only a part of their research covering general financing of higher education issues. So, a fresh study exclusively addressing the vital dimensions of the education loan by commercial banks are addressed in this study.

\section{Objectives of the Study}

The general objectives of the present study include:

- To discuss the status of higher education in India so as to analyse the current trend and patterns.

- To examine the trend, pattern and structure of education loan in India, and, finally,

- To analyse the regional and state-wise distribution of education loan in India.

\section{Materials and Methods}

The study is primarily based on secondary data. Data on education loan released by the Reserve Bank of India, Report of the All India Survey on Higher Education conducted by the MHRD, IBA Bulletin and so on are widely used. For the analysis, we have used annual growth rates and compound annual growth rates (CAGR).

\section{Higher Education Growth in India}

The institutional infrastructure for the provision of higher education in the country has grown manifold in the last several decades. The higher economic growth, the increasing aspirations of the adult population 
and the opportunities thrown by the globalisation have led to spectacular demand for higher education. This has resulted in setting up of various institutions in the sphere of higher education. As the Table 1 shows, there were 53,620 higher education institutions, 3.50 crores students and 14.04 lakhs teachers in our higher education landscape during 2018-19. The type-wise distribution of the institutions shows that 78.1 per cent are colleges, 20 per cent belong to standalone nature and universities comprise 1.9 per cent.

Table 1: Status of Higher Education in India

\begin{tabular}{lccc}
\hline Institutions & Number & Teachers (in Lakhs) & Students (lakbs) \\
\hline Universities & 993 & 1.58 & 69.46 \\
Colleges & 41901 & 10.99 & 260.00 \\
Stand Alone Institutions & 10726 & 1.47 & 20.23 \\
Total & 53620 & 14.04 & 349.69 \\
\hline
\end{tabular}

Source: All India Survey on Higher Education 2018-19, MHRD, Government of India

A look at the structure of the universities shows that the state public and state private universities form 68 per cent of the whole system of universities. Thus, it is clear that these two systems offer higher enrolment for higher education in India. So, the quality and quantity of higher education in India is very much dependent on the way in which these two institutions impart their education. The details of the distribution of university level institutions in India is provided in Table 2.

Table 2: Distribution of University Level Institutes-Type Wise (\%)

\begin{tabular}{llrlllr}
\hline Sl. No. Institutions & $\%$ & Sl. No. Institutions & $\%$ \\
\hline 1 & State Public University & 37.4 & 7 & State Open University & 1.4 \\
2 & State Private University & 30.6 & 8 & $\begin{array}{l}\text { Deemed University (Government- } \\
\text { Aided) }\end{array}$ & 1.0 \\
& & & & & \\
& & 12.8 & 9 & Institutes under State Legislative Act & 0.5 \\
4 & Institute of National Importance & Deemed University (Private) & 4.1 & 10 & State Private Open University & 0.1 \\
5 & Deemed University (Government) & 4.6 & 11 & Central Open University & 0.1 \\
& Central University & & & & Total & 100.0 \\
\hline
\end{tabular}

Source: Ibid

\subsection{Distribution of Colleges and Standalone Institutions-Management wise}

On the basis of funding, there are three categories of institutions in India. They are: (a) Institutions set up and run by the Government, (b) private-aided education institutions receiving grants from the government, and (c) private unaided or fully self-funded institutions. Until the beginning of 1990, the 
management of the education sector was dominated by government and private-aided institutions. The latter were set up and managed by religious, charitable and philanthropic organisations termed as fused private-public entities. As Rani (2016) has rightly pointed out that the private unaided category has become increasingly important from the 1990s especially in professional education, because government and government-aided institutions have been unable to meet the rapidly growing demand for higher education.

The Report of the All India Higher Education Survey 2019 reveals that about 77.8 per cent of the colleges are under the private sector, of which 64.3 per cent are in the private unaided category and 13.5 per cent are private aided sector. Only 22.2 per cent of the college level institutions are managed by the government sector. There are wide variations among states in the number of private colleges. Andhra Pradesh and Uttar Pradesh have about 88 per cent of private unaided colleges and Tamil Nadu has 78 per cent private unaided colleges, whereas, it is only 16 per cent in Assam. Even in a state with Marxist philosophy woven government viz., Kerala, the larger chunk of the higher education infrastructure is set up and managed by the private sector. Table 3 gives information about the type of colleges in India and Kerala management-wise. When we look at the management of the college level institutions, the largest segment of higher education network in the country, one can see that private unaided sector is the largest, forming the lion share at the all India level as well as the state level.

Table 3: Distribution of Colleges in India and Kerala Management-wise (2018-19)

\begin{tabular}{llrrrr}
\hline Sl.No. & Type of college & \multicolumn{2}{c}{ Kerala } & \multicolumn{2}{c}{ India } \\
\cline { 3 - 6 } & & Number & \% to total & Number & \% to total \\
\hline 1 & Private- Unaided & 828 & 64.69 & 24541 & 64.28 \\
2 & Private-Aided & 204 & 15.94 & 5148 & 13.48 \\
& Total Private & 1032 & 80.63 & 29689 & 77.76 \\
3 & Government & 248 & 19.37 & 8490 & 22.24 \\
& Total & 1280 & 100.00 & 38179 & 100.00 \\
\hline
\end{tabular}

Source: Ibid

In the case of Stand-alone institutions (not affiliated with Universities) private sector occupies 75.5 per cent of the total higher education institutions. A bifurcation of the private sector stand-alone institutions shows that 66.20 per cent are under private unaided and 9.30 per cent in private aided sector. So, the analysis of the institutional infrastructure for higher education from the university to stand-alone institutions brings out the fact that private sector plays a pivotal role.

\subsection{Enrolment in Colleges}

We have seen that the private sector operates almost one-third of college level higher education institutions in our country. This feature is reflected in the enrolment also. We have already seen that of the total 3.50 crore students' population in the country, about 2.60 cores study in colleges. Table 4 provides the current 
enrolment pattern in colleges during 2018-19. We have made a comparison of the country with Kerala, a state with left orientation in public policy. A close look at the table reveals that 66.41 per cent of the college students in India are enrolled with private sector. While the percentage of students in private colleges constitute 83.18 in Kerala, which is an indication of the downsizing of government in the sphere of higher education even in a radical and progressive state of the country. Kerala is always speaking against liberalism and privatisation whether the left or the right comes to power. But, the reality is that private sector looms in the sphere of education in general and higher education in particular in Kerala.

Table 4: Enrolment in Private and Government Colleges in 2018-19

\begin{tabular}{llrrrr}
\hline Sl.No & Type & \multicolumn{2}{c}{ Kerala } & \multicolumn{2}{c}{ India } \\
\cline { 3 - 5 } & & Number & \% to total & Number & \% to total \\
\hline 1 & Private- Unaided & 346706 & 47.69 & 11961980 & 45.20 \\
2 & Private-Aided & 258069 & 35.49 & 5614527 & 21.21 \\
3 & Total Private & 604775 & 83.18 & 17576507 & 66.41 \\
4 & Government & 122277 & 16.82 & 8888942 & 33.59 \\
& Total & 727052 & 100.00 & 26465449 & 100.00 \\
\hline
\end{tabular}

Source: Ibid

A temporal analysis of the growth of higher education institutions in India as given in Table 5 shows that the role of government institutions is shrinking and private sector is swelling. Both in terms of number of institutions and enrolment the same trend can be seen. So, the economic policy of privatisation and liberalisation has been consistently coming up in the field of higher education. The New Education Policy 2020 has also given thrust to private and foreign capital to the education sector.

Table 5: Distribution of Higher Education Institutions and Enrolment between Government and Private sector in India

\begin{tabular}{|c|c|c|c|c|}
\hline Type & $2000-01^{*}$ & $2005-06^{*}$ & $2010-11$ & 2018-19 \\
\hline \multicolumn{5}{|c|}{ Percentage share of institutions } \\
\hline Government & 33.2 & 25.0 & 26.8 & 22.2 \\
\hline Private Aided & 42.1 & 32.0 & 14.2 & 13.5 \\
\hline Private Unaided & 24.7 & 43.0 & 59.0 & 64.3 \\
\hline Total & 100.0 & 100.0 & 100.0 & 100.0 \\
\hline \multicolumn{5}{|c|}{ Percentage share in enrolment } \\
\hline Government & 41.0 & 35.8 & 39.2 & 33.6 \\
\hline Private Aided & 37.3 & 33.5 & 23.8 & 21.2 \\
\hline Private Unaided & 21.7 & 30.7 & 37.0 & 45.2 \\
\hline Total & 100 & 100 & 100 & 100 \\
\hline
\end{tabular}

Source: (i)*Agarwal, P (2009), (ii) All India Survey on Higher Education 2010-11 and 2018-19 


\subsection{Gross Enrolment Ratio (GER)}

One of the cardinal measure of the growth in enrolment is the Gross Enrolment Ratio (GER). It shows the access to higher education in the population age group of 18-23 years. In developed countries, their GER is above 50 per cent. In 2018-19, India's GER in higher education was 26.4, whereas globally it varies from an average of 8 per cent in sub-Saharan Africa to 75 per cent in Europe and North America. We are nowhere nearer to the Scandinavian countries. In states like Kerala with universal primary and secondary education, the GER of higher education is only 37 per cent. The social stratification of GER also shows the miserable position of the Scheduled Castes and Scheduled Tribes. Table 6 makes a comparison of GER of Higher Education in India with that of Kerala on the basis of caste and gender.

Table 6: GER in Higher Education (2018-19)

\begin{tabular}{lccccccccc}
\hline Region & \multicolumn{3}{c}{ All Categories } & \multicolumn{3}{c}{ Scheduled Castes } & \multicolumn{3}{c}{ Scheduled Tribes } \\
\cline { 2 - 10 } & Male & Female & Total & Male & Female & Total & Male & Female & Total \\
\hline Kerala & 30.8 & 43.2 & 37.0 & 18.2 & 33.7 & 25.9 & 18.9 & 27.1 & 23.1 \\
India & 26.3 & 26.4 & 26.3 & 22.7 & 23.3 & 23.0 & 17.9 & 16.5 & 17.2 \\
\hline
\end{tabular}

Source: Ibid

From the above discussion on the status of higher education in India, it is clear that we have to go a long way to provide higher education to at least 50 per cent of her eligible population. The demographic dividend of the country and the globalisation of employment opportunities cast heavy demand for higher education on a hither to unexpected scale. However, the neo-liberal policies of the government have put drastic reduction on subsidies in general and education sector is not an exception. This has resulted in the proliferation of unaided and self-financing institutions in every nook and corner of the country who runs educational programmes with high fees. This has created the problem of inequity in the system such that only the economically well-off families can afford to the increasing cost of education. In order to tide over the situation, the Government of India has experimented with Education Loan scheme on a wider scale from the year 2001. The motto of the scheme is provision of education at affordable costs with equity to the poor and meritorious students.

Now, almost two decades have been passed after the Model Education Loan Scheme is in operation in our country. This scheme is a golden opportunity to both the student community and bankers. On the one hand it is an opportunity for the banks to introduce a new portfolio for loan disbursement and on the other hand it is an opportunity for the meritorious, but, economically poor students to enrol for their desired courses of study. Let us now turn to examine the performance of education loan in our country.

\section{Education Loan in India}

Education loan scheme is not new to Indian environment. As early in 1963, the Central Government of India had introduced a scheme for providing financial assistance to students named as the National 
Loan Scholarship Scheme. Actually it was managed by the government by providing direct financial assistance to the needy and poor. However, due to several problems like high overdue and lack of vision, the government was forced to withdraw the scheme by 1991. Then quite for one decade there was no such scheme in the country. However, the renewed interest in providing financial support to the poor, but meritorious students emerged by the year 2000 and accordingly the commercial banks were directed to promote education loan. During this time, the Indian Banks Association (IBA) developed a scheme which was then approved by the Reserve Bank of India in the year 2001. This has come to be known as the Model Education Loan Scheme. Since then the Commercial Banks have been directly involved in providing education loan based on the regulation contained in this loan scheme. The Model Education Loan Scheme insists that education loans up to Rs.4 lakhs do not require any collateral from the borrower. While education loan up to Rs.7.5 lakh demands collateral in the form of a third-party guarantee and loan above Rs.7.5 lakhs insist on tangible collateral. Over the years, the disbursement and number of beneficiaries of education loan has increased manifold as seen from Table 7.

Table 7: Outstanding Education loans in India

\begin{tabular}{|c|c|c|c|c|}
\hline Year & Accounts & Annual Growth & Amount (₹. Crores) & Annual Growth \\
\hline $2000-01$ & 112000 & - & 1028.00 & - \\
\hline $2001-02$ & 157000 & 40.18 & 1527.00 & 48.54 \\
\hline $2002-03$ & 239000 & 52.23 & 2870.00 & 87.95 \\
\hline 2003-04 & 347000 & 45.19 & 4179 & 45.61 \\
\hline 2004-05 & 489445 & 41.05 & 6694.33 & 60.19 \\
\hline 2005-06 & 668351 & 36.55 & 11296.39 & 68.75 \\
\hline 2006-07 & 1026215 & 53.54 & 14390.99 & 27.39 \\
\hline 2007-08 & 1247083 & 21.52 & 20258.48 & 40.77 \\
\hline 2008-09 & 1613444 & 29.38 & 27746.62 & 36.96 \\
\hline 2009-10 & 1972053 & 22.23 & 36923.74 & 33.07 \\
\hline $2010-11$ & 2287843 & 16.01 & 42992.84 & 16.44 \\
\hline 2011-12 & 2464124 & 7.71 & 48220.33 & 12.16 \\
\hline $2012-13$ & 2590045 & 5.11 & 52738.67 & 9.37 \\
\hline 2013-14 & 2681360 & 3.53 & 57164.17 & 8.39 \\
\hline 2014-15 & 2671316 & -0.37 & 59336.04 & 3.80 \\
\hline $2015-16$ & 2636624 & -1.30 & 61831.00 & 4.20 \\
\hline $2016-17$ & 2547246 & -3.39 & 62854.00 & 1.65 \\
\hline 2017-18 & 2427512 & -4.70 & 61773.00 & -1.72 \\
\hline 2018-19 & 2307871 & -4.93 & 62456.00 & 1.11 \\
\hline CAGR (\%) & & 18 & & 26 \\
\hline
\end{tabular}

Source: Statistics on Indian Economy, Reserve Bank of India 
As it is seen from the table that the initial momentum of education loan has lost in the later periods. The annual growth rates fluctuate throughout the period. While the CAGR of education loan account was found to be 18 per cent, the amount of education loan showed 26 per cent. In brief, though there has been commendable increase in the outstanding education loan from the commercial banks, later years witnessed some lapses on the part of the banking sector. The data in Table 8 shows actual disbursement to education loan by public sector banks, which is the largest segment of commercial banks who is participating in the scheme. Lack of consistency both in the number of accounts and amounts sanctioned shows the indifference of the banking sector to finance education.

Table 8: Disbursement of Education Loan by Public Sector Banks in India

\begin{tabular}{lrrrr}
\hline Financial Year & $\begin{array}{r}\text { No. of } \\
\text { Accounts }\end{array}$ & $\begin{array}{c}\text { Annual } \\
\text { Growth }\end{array}$ & $\begin{array}{r}\text { Education Loan } \\
\text { Disbursed (F Crore) }\end{array}$ & Annual Growth \\
\hline $2014-15$ & 681685 & - & 9190.45 & - \\
$2015-16$ & 684836 & 0.46 & 12595.39 & 37.05 \\
$2016-17$ & 599729 & -12.43 & 11175.91 & -11.27 \\
$2017-18$ & 786312 & 31.11 & 13470.47 & 20.53 \\
$2018-19$ & 696656 & -11.40 & 15030.13 & 11.58 \\
CAGR (\%) & & 1 & & 13 \\
\hline
\end{tabular}

Source: Loksabha, Unstarred Question No.2189, 02 December 2019, Government of India

\subsection{Education Loan and Priority Sector credit}

As per the RBI norms, education loans up to ₹ 7.50 lakh for studies in India and ₹ 15 lakhs for studies abroad respectively were treated as priority sector advances based on the order issued in 2003. Later, in 2015, this ceiling has been enhanced. Now, the education loan to individuals for the purpose of education including vocational courses up to ₹ 10 lakhs irrespective of the sanctioned amount will be considered as eligible for priority sector. A close look at the Table 9 reveals that education loan constituted around 3.93 per cent of total personal loan in 2007-08. In 2018-19, this percentage has come down to 3.06. Education loan as percentage to total priority sector loans ranges between 2.33 to 3.42 during the period of study. Thus, it is seen that education loan as percentage of outstanding personal loans and priority sector loans do not show encouraging growth during the period under consideration.

\subsection{Regional/State-wise Distribution of Education Loan}

It is interesting to examine the disbursement of education loan in India among the various states and regions. The details are presented in Table 10. 
Financing Higher Education through Education Loan in India: Current Status, Challenges and Future Prospects

Table 9: Deployment of Bank Credit Outstanding by Major Sectors

(Amount in ₹ Crores)

\begin{tabular}{|c|c|c|c|c|c|c|}
\hline Year & $\begin{array}{r}\text { Total } \\
\text { Outstanding } \\
\text { Personal } \\
\text { Loans }\end{array}$ & $\begin{array}{r}\text { Education } \\
\text { Loan } \\
\text { Outstanding } \\
\text { Under Personal } \\
\text { Loans }\end{array}$ & $\begin{array}{l}\text { Column (3) } \\
\text { as Percenge of } \\
\text { Column (2) }\end{array}$ & $\begin{array}{r}\text { Total Priority } \\
\text { Sector } \\
\text { Loan }\end{array}$ & $\begin{array}{r}\text { Education Loan } \\
\text { Under Priority } \\
\text { Sector }\end{array}$ & $\begin{array}{r}\text { Column (6) } \\
\text { as Percentage } \\
\text { of Column } \\
\text { (5) }\end{array}$ \\
\hline 1 & 2 & 3 & 4 & 5 & 6 & 7 \\
\hline $2007-08$ & 521799 & 20532 & 3.93 & 748073 & 19441 & 2.60 \\
\hline 2008-09 & 562479 & 28579 & 5.08 & 932459 & 27861 & 2.99 \\
\hline $2009-10$ & 585633 & 36863 & 6.29 & 1092179 & 36247 & 3.32 \\
\hline 2010-11 & 687944 & 42704 & 6.21 & 1262179 & 42589 & 3.37 \\
\hline 2011-12 & 782835 & 49933 & 6.38 & 1421045 & 48067 & 3.38 \\
\hline $2012-13$ & 897584 & 54970 & 6.12 & 1539796 & 52612 & 3.42 \\
\hline 2013-14 & 1009689 & 60005 & 5.94 & 1829724 & 57888 & 3.16 \\
\hline 2014-15 & 1166348 & 63320 & 5.43 & 2010324 & 59184 & 2.94 \\
\hline 2015-16 & 1392216 & 68224 & 4.90 & 2225907 & 60137 & 2.70 \\
\hline 2016-17 & 1620034 & 70088 & 4.33 & 2435647 & 60436 & 2.48 \\
\hline 2017-18 & 1908469 & 69712 & 3.65 & 2553187 & 60713 & 2.38 \\
\hline 2018-19 & 2220732 & 67988 & 3.06 & 2739021 & 63950 & 2.33 \\
\hline CAGR( $(\%)$ & 14 & 11 & - & 13 & 11 & - \\
\hline
\end{tabular}

Source: Handbook of Statistics on the Indian Economy, Reserve Bank of India

Table 10: State-wise Distribution of Priority Sector Advances and Education loan by Scheduled Commercial Banks (As on March 2019)

(No. of Accounts in absolute terms; Amount in ₹ Crore)

\begin{tabular}{|c|c|c|c|c|}
\hline \multirow[t]{2}{*}{ State/Region } & \multicolumn{2}{|c|}{ Total Priority Sector } & \multicolumn{2}{|c|}{ Education Loan } \\
\hline & $\begin{array}{l}\text { No. of } \\
\text { Accounts }\end{array}$ & $\begin{array}{r}\text { Balance } \\
\text { Outstanding }\end{array}$ & $\begin{array}{c}\text { No. of } \\
\text { Accounts }\end{array}$ & $\begin{array}{r}\text { Balance } \\
\text { Outstanding }\end{array}$ \\
\hline Northern Region & 13861008 & 647800.71 & 170989 & 5994.85 \\
\hline Chandigarh & 148808 & 13971.72 & 4077 & 164.72 \\
\hline Delhi & 815180 & 144165.38 & 33556 & 1379.26 \\
\hline Haryana & 2561058 & 126411.91 & 31024 & 1064.74 \\
\hline Himachal Pradesh & 520574 & 16842.21 & 13461 & 360.03 \\
\hline Jammu \& Kashmir & 781051 & 27075.63 & 13067 & 336.64 \\
\hline Punjab & 3048401 & 132431.19 & 29341 & 1293.81 \\
\hline
\end{tabular}

contd. table 10 
Krishnan Chalil

\begin{tabular}{|c|c|c|c|c|}
\hline \multirow[t]{2}{*}{ State/Region } & \multicolumn{2}{|c|}{ Total Priority Sector } & \multicolumn{2}{|c|}{ Education Loan } \\
\hline & $\begin{array}{l}\text { No. of } \\
\text { Accounts }\end{array}$ & $\begin{array}{r}\text { Balance } \\
\text { Outstanding }\end{array}$ & $\begin{array}{l}\text { No. of } \\
\text { Accounts }\end{array}$ & $\begin{array}{r}\text { Balance } \\
\text { Outstanding }\end{array}$ \\
\hline Rajasthan & 5985936 & 186902.67 & 46463 & 1395.66 \\
\hline North Eastern Region & 4633478 & 47970.83 & 22281 & 661.66 \\
\hline Arunachal Pradesh & 34186 & 1407.77 & 509 & 14.90 \\
\hline Assam & 3597542 & 34605.04 & 14130 & 421.30 \\
\hline Manipur & 99883 & 2181.23 & 785 & 26.58 \\
\hline Meghalaya & 115197 & 2037.10 & 3026 & 86.46 \\
\hline Mizoram & 38964 & 1036.38 & 425 & 12.34 \\
\hline Nagaland & 64113 & 1084.00 & 363 & 11.21 \\
\hline Tripura & 683593 & 5619.32 & 3043 & 88.87 \\
\hline Central Region & 20472790 & 470156.40 & 224160 & 6677.77 \\
\hline Chatisgarh & 1524686 & 42163.00 & 19809 & 560.49 \\
\hline Madhya pradesh & 6704815 & 160917.66 & 71794 & 2126.81 \\
\hline Uttarakhand & 1961661 & 59556.80 & 39422 & 1261.62 \\
\hline Uttar Pradesh & 10281628 & 207518.94 & 93135 & 2728.86 \\
\hline Eastern Region & 25300155 & 317812.84 & 244685 & 7781.43 \\
\hline Andaman \& Nicobar & 18493 & 926.24 & 392 & 12.71 \\
\hline Bihar & 7374024 & 66915.27 & 92828 & 3031.39 \\
\hline Jharkhand & 2518527 & 33301.61 & 43944 & 1614.39 \\
\hline Odisha & 5025482 & 56994.43 & 49349 & 1442.45 \\
\hline Sikkim & 191725 & 1605.65 & 458 & 13.19 \\
\hline West Bengal & 10171904 & 158069.64 & 57914 & 1667.31 \\
\hline Western Region & 17818915 & 1180978.44 & 253856 & 7368.03 \\
\hline Dadra \& Nagar Haveli & 15048 & 1352.84 & 262 & 7.91 \\
\hline Daman \& Diu & 7079 & 750.20 & 186 & 6.52 \\
\hline Goa & 160645 & 7552.93 & 4412 & 132.02 \\
\hline Gujarat & 5100063 & 241036.33 & 45593 & 1639.88 \\
\hline Maharashtra & 12536080 & 930286.15 & 203403 & 5581.70 \\
\hline Southern Region & 57278170 & 1075234.29 & 1391900 & 33972.70 \\
\hline Andhra Pradesh & 9452325 & 194780.44 & 92299 & 3387.28 \\
\hline Karnataka & 9614160 & 209922.33 & 195411 & 4744.91 \\
\hline Kerala & 8578482 & 163388.67 & 294479 & 7957.76 \\
\hline Lakshadweep & 2838 & 39.21 & 24 & 0.77 \\
\hline Puducherry & 467614 & 6354.14 & 12166 & 273.34 \\
\hline Tamil Nadu & 24747427 & 381227.30 & 742740 & 15017.51 \\
\hline Telangana & 4415324 & 119522.20 & 54781 & 2591.14 \\
\hline All India & 139364516 & 3739954.00 & 2307871 & 62456.00 \\
\hline
\end{tabular}

Source: Ibid 
The region-wise and state-wise distribution of education loan as provided in Table 10 reveals the existence of glaring inequality among the various regions and states of the country. Both in terms of education loan accounts and loan amount, the Southern Region and the states under it bagged lion share. About 54.39 per cent of the education loan was availed by the states of south India. Whereas, the bigger states like Uttar Pradesh, Madhya Pradesh, Bihar etc., could not make use of education loan scheme in a better way. While the northern region received 9 per cent of education loan, the North East could enjoy only one percent of the education loan. The situation of eastern region $(13 \%)$, western region $(12 \%)$ and central region $(10 \%)$ are nowhere near to the level of southern region. At the same time, the default of education loan is also found to be the highest in southern region.

In order to understand the performance of south Indian states in the field of education loan, we provide an analysis for the last 15 years. The Tables 11 and 12 give details on the distribution of education loan among the states of south India. A close look at the table shows that Tamil Nadu has the highest number of education loan accounts since 2004-05, followed by Kerala. Tamil Nadu alone accounts for 53.36 per cent of the education loan accounts of south Indian states. In the case of education loan amount, Tamil Nadu alone appropriated 44.20 per cent of the total loan outstanding of the southern region. The increasing demand for professional higher education may be the prime reason for the higher level of application for the loan. The same fact is attested by the Care Ratings (2018) in its report while stating that the education loans are skewed towards south Indian regions primarily due to the preference given to technical and professional education. These are all the startling evidences of regional inequality persisting in one of the most acclaimed schemes meant for the promotion of human capital.

Table 11: Distribution of Education Loan Accounts in South Indian States

\begin{tabular}{|c|c|c|c|c|c|c|c|}
\hline Year & Andhra Pradesh & Karnataka & Kerala & TamilNadu & Telangana & $\begin{array}{r}\text { Total South } \\
\text { India }\end{array}$ & $\begin{array}{r}\text { All India } \\
\text { Total }\end{array}$ \\
\hline 2004-05 & 88014 & 46273 & 68583 & 88707 & - & 293896 & 489445 \\
\hline 2005-06 & 105923 & 65110 & 107003 & 132586 & - & 413577 & 668351 \\
\hline $2006-07$ & 149257 & 87229 & 156061 & 225337 & - & 622827 & 1026215 \\
\hline $2007-08$ & 166493 & 113403 & 157277 & 314923 & - & 758169 & 1247083 \\
\hline 2008-09 & 195659 & 138650 & 215976 & 418100 & - & 976394 & 1613444 \\
\hline $2009-10$ & 218491 & 161085 & 246974 & 574690 & - & 1211197 & 1972053 \\
\hline $2010-11$ & 220779 & 172783 & 289998 & 717261 & - & 1412078 & 2287843 \\
\hline 2011-12 & 215797 & 173270 & 308097 & 822810 & - & 1532375 & 2464124 \\
\hline $2012-13$ & 197032 & 186623 & 336212 & 886752 & - & 1621275 & 2590045 \\
\hline 2013-14 & 190340 & 195169 & 341427 & 940990 & - & 1682763 & 2681360 \\
\hline 2014-15 & 170678 & 198709 & 331663 & 960202 & - & 1675881 & 2671316 \\
\hline 2015-16 & 104358 & 203474 & 323433 & 891532 & 69390 & 1606024 & 2636624 \\
\hline 2016-17 & 100026 & 202558 & 269010 & 906412 & 64145 & 1555514 & 2547246 \\
\hline 2017-18 & 95305 & 199942 & 313356 & 821454 & 52916 & 1502802 & 2427512 \\
\hline 2018-19 & 92299 & 195411 & 294479 & 742740 & 54781 & 1391900 & 2307871 \\
\hline CAGR(\%) & 0 & 11 & 11 & 16 & -8 & 12 & 12 \\
\hline
\end{tabular}

Source: Ibid 
Krishnan Chalil

Table 12: Distribution of Education Loan Amounts in South Indian States

(Figures in ₹ crores)

\begin{tabular}{lrrrrrrr}
\hline Year & Andhra Pradesh & Karnataka & Kerala & Tamil Nadu & Telangana & $\begin{array}{r}\text { Total South } \\
\text { India }\end{array}$ & $\begin{array}{r}\text { All India } \\
\text { Total }\end{array}$ \\
\hline $2004-05$ & 1352.32 & 551.84 & 757.06 & 1001.41 & - & 3685.88 & 6694.33 \\
$2005-06$ & 2023.19 & 891.65 & 1374.54 & 1863.38 & - & 6192.78 & 11296.39 \\
$2006-07$ & 2232.23 & 1154.51 & 1849.90 & 2363.08 & - & 7755.47 & 14390.99 \\
$2007-08$ & 2977.15 & 1752.98 & 2414.74 & 3592.07 & - & 10797.93 & 20258.48 \\
$2008-09$ & 3970.20 & 2432.33 & 3141.59 & 5184.59 & - & 14830.29 & 27746.62 \\
$2009-10$ & 4843.06 & 2915.55 & 4874.34 & 7351.67 & - & 20123.32 & 36923.74 \\
$2010-11$ & 5091.83 & 3216.25 & 5282.10 & 9582.28 & - & 23343.62 & 42992.84 \\
$2011-12$ & 5058.56 & 3518.39 & 5854.58 & 11709.03 & - & 26348.37 & 48220.33 \\
$2012-13$ & 4698.58 & 3874.54 & 7353.91 & 13343.65 & - & 29535.47 & 52738.67 \\
$2013-14$ & 4987.76 & 4062.52 & 7975 & 15077 & - & 32396.25 & 57164.17 \\
$2014-15$ & 5443.33 & 4159.33 & 7788.53 & 16313.06 & - & 33993.62 & 59336.04 \\
$2015-16$ & 3461.20 & 4610.26 & 8385.58 & 15297.50 & 3300.93 & 35339.06 & 61831.00 \\
$2016-17$ & 3389.86 & 4621.62 & 7852.71 & 15725.98 & 3011.21 & 34885.90 & 62854.00 \\
$2017-18$ & 3353.69 & 4444.77 & 8388.84 & 15883.87 & 2822.38 & 35186.97 & 61773.00 \\
$2018-19$ & 3387.28 & 4744.91 & 7957.76 & 15017.51 & 2591.14 & 33972.70 & 62456.00 \\
CAGR(\%) & 7 & 17 & 18 & 21 & -8 & 17 & 17 \\
\hline SOMre: & & & & & & &
\end{tabular}

Source: Ibid

\subsection{Education Loan and Non-Performing Assets (NPA)}

One of the major challenges that the education loan has been facing is that of higher level of defaults. As per the banking principle, the timely repayment of loans is a pre-requisite for its onward lending. Despite several efforts, it is unfortunate to see that the NPA of education loans is the highest among all loans. While Tamil Nadu and Kerala bagged more than one-third of education loan, in the case of education loan NPA, these two states exhibited higher delinquencies. The data of the State Level

Table 13: Programme-wise Status of NPA of Education Loan Disbursed by Public Sector Banks (PSBs)

\begin{tabular}{llc}
\hline Sl. No & Programme & $\begin{array}{c}\text { \% of educational loans which } \\
\text { become NPAs }\end{array}$ \\
\hline 1 & Nursing & 21.28 \\
2 & Engineering & 9.76 \\
3 & Other Professional courses & 9.49 \\
4 & Medical & 6.06 \\
5 & MBA & 5.59 \\
\hline
\end{tabular}

Source: Akanksha Soni (2019), The Hindu, January 14 
Bankers Committee of Kerala and Tamil Nadu showed that their Gross NPA percentages are above 10 per cent as compared with the overall delinquencies at 7.67 per cent at Pan India Level. Other States such as Andhra Pradesh, Telangana and Madhya Pradesh, the Gross NPA percentage were around 5 per cent. When we look at the stream-wise status of NPA, one can see that Nursing sector and other professional courses like Engineering and even Medical courses exhibit exorbitant level of NPAs. Table 13 gives a glimpse of the level of NPA in various programme.

Several reasons could be attributed to the higher levels of default in the education loan. According to the Care Ratings (2018), the delinquencies in the PSBs in this segment have been higher on account of loans being unsecured in nature and also as these loans are funded for graduation courses which have lower employment opportunities. It is generally agreed that the primary reason for stress in education loans is non-insistence of any collateral against small window loans (below ₹ 4 lakhs earlier, now increased to ₹. 7.5 lakh). In addition to this, lower employment opportunities after completion of the course, lower salaries in the nursing sector, and uncertainty in the job prospects abroad are also seem to be prime factors for non-repayment of these loans. The economic growth and its corresponding job prospects had a setback in recent years as seen in the deceleration in campus placement. Engineering, where nearly 10 per cent of the education loans has become NPAs, has a bad placement record in recent years. Only about 46 per cent of the students who graduated from government and private engineering colleges across the country in 2016-17 managed to obtain a job placement, according to data given in the Rajya Sabha in July 2018.

\section{Results and Discussion}

The human capital based development model of the new world order have pushed education to the centre stage. The endogenous growth model popularised during the 1980s have given thrust to knowledge and research as pivotal agents of growth. Consequent on these developments, all the countries have initiated steps to increase the space for higher education to the maximum people. Promotion of domestic private investment and even foreign investment to the education infrastructure is dominant since 1991. In India also, the proliferation of unaided and self-financing stream in the education sphere is a common scene in the last few decades. The situation is the same across the country including states like Kerala with a strong leftist ideology. They are highly dominant in the provision of professional and technical education which requires payment of huge fee for admission. Most often, the household alone cannot afford to such exorbitant fee structure. So, as a soft option, support from banks has come to the forefront. With the announcement of the Model Education Loan Scheme in 2001, the commercial banks have been financing the education expenses of the students who are enrolled for such programme of studies specified therein.

From the foregoing discussion, it is clear that there has been spectacular growth in the number of higher education institutions and enrolment in higher education in India. However, one point is very evident that these growth have occurred mainly through the private institutions. These private universities and unaided colleges are sustained through charging higher fees from the students. But in a country like India with extreme poverty and inequality, majority of the student population are unable to support their education by their own resources. So they may recourse to some alternative 
financing mechanisms like education loans. The tremendous rise in the number of accounts and amounts under the education loan portfolio is a testimony of the popularity of education loan scheme in India. However, the recent decline in the number of education loan accounts is a matter of serious concern. The increasing share of Non-Performing Assets under the education loan is considered as one of the major reasons for the disinterest shown by the bankers in extending more education loan. It is also seen that the banks are more interested in providing higher ticket loans with collateral while sanctioning education loan.

Another disquieting feature of the education loan in the country is its uneven distribution among various states and regions. While the south Indian states could bag around 60 per cent of the education loan, the north and north-eastern states are lagging far behind. Two states namely Tamil Nadu and Kerala alone bagged around 36 per cent of total education loan. So, this skewed distribution of education loan raises doubts regarding the efficacy of the education loan scheme as an alternative to the conventional funding mechanism.

Adding to the above, though the education loan is included in the priority sector lending, the proportion of education loan to the total priority sector lending is almost stagnant during the years. Similarly, in the case of annual of disbursement of education loan, there has been an increasing trend, but, the growth of loan accounts is declining further. This is attributed to the preference of banks in sanctioning high ticket loan with collateral security. This may lead to a situation that the needy, but, poor will be excluded from the purview of education loan in the near future. Similarly, the higher delinquency rate of education loan is also to be viewed seriously. India has to go a long way to ensure higher education to a large segment of adult population in the age group of 18-23 years. As the increasing cost of education denies access to higher education to the poor and marginalised, an effective education financing mechanism like education loan is the only way out. This warrants restructuring of the existing education loan with much emphasis on equity and access to poor students.

\section{Conclusion}

So, every effort is needed to be carried out to maintain the education loan scheme effective for inclusive growth. The avowed objective of the scheme could be achieved only when this scheme is implemented across the states and regions more or less evenly. With the rising share of self-financing and unaided sector in higher education, the fee structure will be on the high side and hence the poor and marginalised are unable to meet their educational expenses from their own resources. To a major extent, education loan can fill this vacuum. So the commercial banks, co-operatives, small finance banks, and the NonBanking Financial Companies should come forward with a sustainable and affordable education loan scheme to promote higher education of the country. Unfortunately, a major chunk of the education loan is currently provided by public sector banks. This aspect has to be considered by the policy bodies. Among the public sector banks, the State Bank of India provides the lion share of education loan. The NPA of education loan also has to be controlled for the sustained provision of education loan. The regional inequality in the distribution of education loan also has to be addressed. So, the future prospects of education loan rely on its even distribution among the regions/states and also how the system addresses the vital issues like high level of NPA and equity concerns. 
Financing Higher Education through Education Loan in India: Current Status, Challenges and Future Prospects

\section{References}

Agarwal, P. (2009). Indian Higher Education: Envisioning the Future, Sage, New Delhi, P. 520.

Barr, N. (1993). Alternative Funding Resources for Higher Education, The Economic Journal, 103(418), 718-728.

Care Ratings (2018). Education Loan Sector in India: Product Differentiation and Specialised Approach Critical for Profitable Growth, Report, March 29, 1-8.

Chattopadhyay, Saumen (2007). Exploring Alternative Sources of Financing Higher Education, Economic and Political Weekly, Oct. 20 - 26, 2007, 42(42), 4251-4259

Duraisamy, P. and Malathy Duraisamy (2016). Contemporary Issues in Indian Higher Education: Privatization, Public and Household Expenditures and Student Loan, Higher Education for the Future, 3(2), 144-163.

Ganguly Shromona and Deepa S. Raj (2020). Education Loan NPAs of Banks in Tamil Nadu: Issues and Challenges, Reserve Bank of India Occasional Papers, 41(2), Mumbai.

Krishnan, C (2020). Role of Financial Institutions in Human Capital Development: Is Education Loan an alternative source of financing higher education in India?, Research Project Report submitted to the Inter University Centre for Alternative Economics, Department of Economics, University of Kerala.

Narayana. M. R. (2005). Student Loan by Commercial Banks: A Way to Reduce State Government Financial Support to Higher Education in India. The Journal of Developing Areas, 38(2), 171-187.

Panigrahi, Jinusha (2010). Determinants of Education Loans by Commercial Banks in India: Evidence and Implications based on a sample survey, Journal of Educational Planning and Administration, 24(4), October, 379-400.

Puttaswamaiah, S. (2010). Financing Higher Education: A Study of Educational Loans, CMDR Monograph Series No. - 61, Centre for Multi-Disciplinary DevelopmentResearch (CMDR), Dharwad.

Rani, G .P (2014), Education Loans and Financing Higher Education in India: Addressing Equity, Higher Education for the Future, Sage, 1(2), 1-28.

Rani, G.P (2016). Financing Higher Education and Education Loans in India: Trends and Troubles, Journal of Social Sciences, 12(4), 182-200.

Rani, G. P. (2017). Financing higher education and education loans in India: interstate differentials and determinants, Journal of Social Economic Development, 19(1), 42-59.

Romer, Paul M. (1990). Endogenous Technical Change, Journal of Political Economy 98(5), October, Part II, S71S102.

Schultz, Theodore W. (1961). Investment in Human Capital, The American Economic Review, Vol. 51, No. 1, March, $1-17$.

Soni, Akanksha (2019). Education Loan NPAs on Rise, The Hindu, e-paper, January 14.

Stiglitz, J E (1998). More Instruments and Broader Goals: Moving toward a Post-Washington Consensus, The 1998 WIDER Annual Lecture, WIDER, Helsinki.

Stiglitz, J E (2003). Information and the Change in the Paradigm in Economics in Richard Arnott, Bruce Greenwald, Ravi Kanbur and Barry Nalebuff (eds), Economics for an Imperfect World: Essays in Honor of Joseph E Stiglitz, The MIT Press, Cambridge.

Subas Tiwari \& Gopal Ravi Kumar (2019). Education Loans for Higher Studies in India Who gives how much and how? Consumer Voice, July, 35-41

Varghese N. V. (2009). Reforming education financing, URL: bttps://www.india-seminar.com/2000/494/ 494\%20n.v.\%20varghese.htm, accessed on 22-01-2021.

Orissa Journal of Commerce, 42(1) (C) 2021 